\title{
Demonstration of MEOR as an alternative enhanced oil recovery technique in Nigeria offshore oilfield
}

Nsisong E. UDOSOH, Thaddeus C. NWAOHA

DOI: $10.30464 /$ jmee.2020.4.3.277

Cite this article as:

Udosoh N. E., Nwaoha T. C. Demonstration of MEOR as an alternative enhanced oil recovery technique in Nigeria offshore oilfield. Journal of Mechanical and Energy Engineering, Vol. 4(44), No. 3, 2020, pp. 277-284.

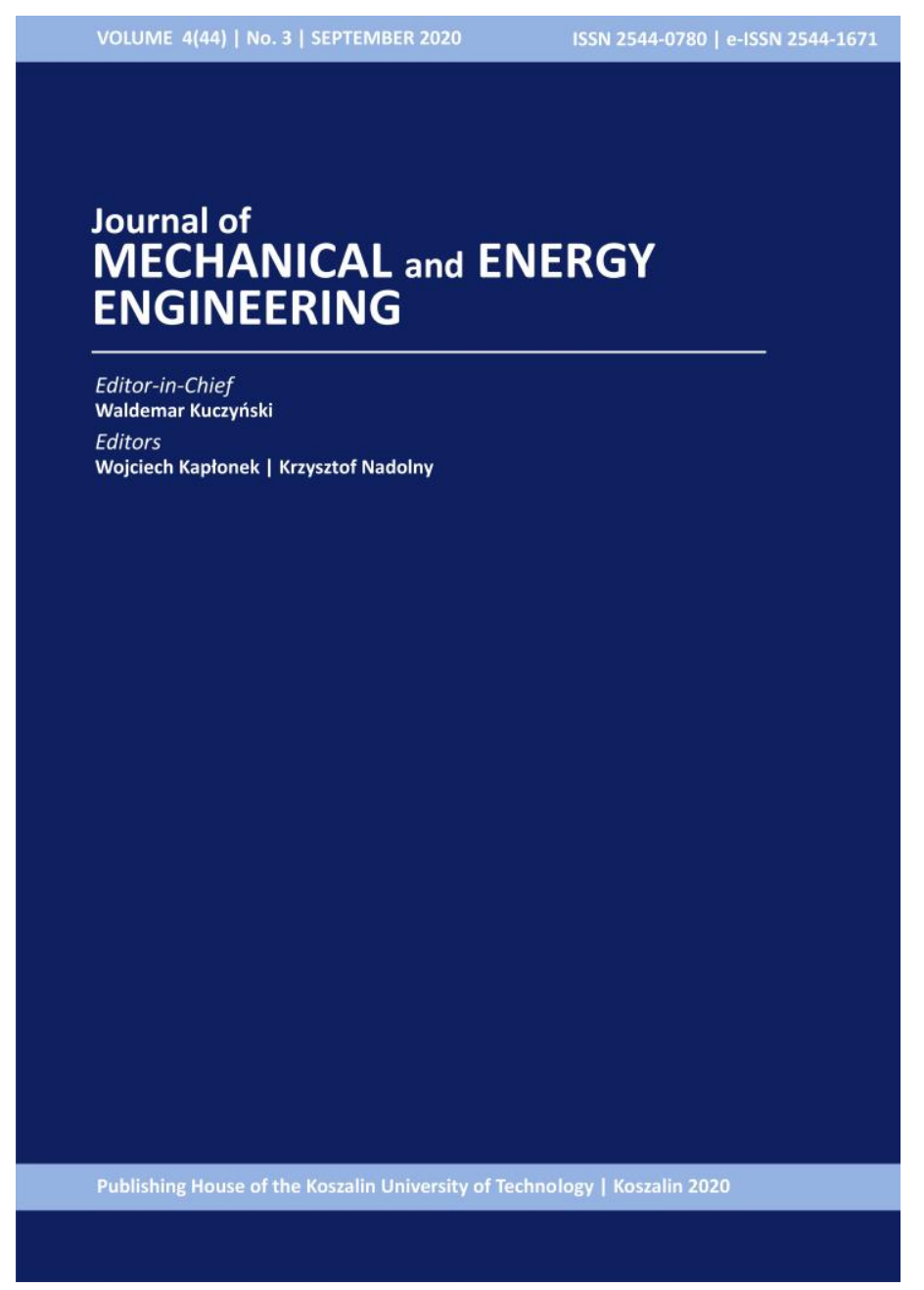

Journal of Mechanical and Energy Engineering

Website: jmee.tu.koszalin.pl

ISSN (Print): 2544-0780

ISSN (Online): 2544-1671

Volume: $4(44)$

Number: 3

Year: 2020

Pages: 277-284

Article Info:

Received 25 September 2020

Accepted 6 November 2020

\section{Open Access}

This article is distributed under the terms of the Creative Commons Attribution 4.0 (CC BY 4.0) International License (http://creativecommons.org/licenses/by/4.0/), which permits unrestricted use, distribution, and reproduction in any medium, provided you give appropriate credit to the original author(s) and the source, provide a link to the Creative Commons license, and indicate if changes were made. 


\title{
DEMONSTRATION OF MEOR AS AN ALTERNATIVE ENHANCED OIL RECOVERY TECHNIQUE IN NIGERIA OFFSHORE OILFIELD
}

\author{
Nsisong E. UDOSOH ${ }^{1 *}$, Thaddeus C. NWAOHA ${ }^{1}$ \\ ${ }^{1 *}$ Department of Marine Engineering, Federal University of Petroleum Resources, Effurun, Delta State, \\ Nigeria
}

(Received 25 September 2020, Accepted 6 November 2020)

\begin{abstract}
Eni oilfield has been experiencing production decline with increase in water output. The implementation of enhanced oil recovery (EOR) can help to extract some percentages of the original oil in place (OOIP). EOR methods are capital intensive and few are environmental hazardous. In a bid to address this issues, this paper discusses on an alternate economically viable enhanced oil recovery technique which has the potential to curb the challenges of other conventional EOR methods. This work suggested a 3 stage approach of applying microbial enhanced oil recovery (MEOR) method for oil recovery in Eni field. The reservoir characteristics in Eni field were studied, the average porosity value of the reservoirs is between 0.238 and 0.241 , while water saturation ranges between 0.127 and 0.13 . Other production data include; Initial reservoir pressure which ranges from 2328 to 2553 Psia and has a reservoir temperature ranging from $170^{\circ} \mathrm{F}$ to $180^{\circ} \mathrm{F}$. The Average API gravity ranges from 20.5 to 34.2 , while the initial GOR ranges from 350 to 396 . Oil viscosity was between $0.57 \mathrm{cp}$ to $2.57 \mathrm{cp}$ while gas viscosity was between $0.65 \mathrm{cp}$ to $0.67 \mathrm{cp}$. The reservoir characteristics and parameters were found suitable for the application of MEOR technique for effective oil drainage from the delineated reservoir compartments. Microbial flooding was found to be matured in reservoirs with temperature less than $200^{\circ} \mathrm{F}$, brine salinity not more than $100,000 \mathrm{ppm}$, water depth not more than $3500 \mathrm{~m}$ and permeability should be above 30 (Md). It is recommended that MEOR approach should be applied in Eni Oilfield for increment of oil production and reduction in water cut due to its efficiency and economic viability.
\end{abstract}

Keywords: eni oilfield, reservoir, permeability, efficiency, microbial, porosity

\section{INTRODUCTION}

An oilfield is a tract of land used for the extraction of petroleum, otherwise known as crude oil from the ground. There are quite 65,000 oilfields round the world, many of the largest is located within the middle east. An oil field consists of oil reservoirs in the rocky strata of the earth which traps hydrocarbons [1]. An oil reservoir can be said to be a subsurface pool of hydrocarbons contained in porous or fractured rocks formations. Today, crude oil is heavily relied on for primary energy. In 2014, the worldwide demand for oil increased by $0.8 \%$ to reach 101 million barrel per day [2]. With constantly rising demand for crude oil worldwide, there is an excellent need for increase in production so as to satisfy the demand. Boring is separated into three (3) phases; primary, secondary and tertiary. Primary recovery has to do with hydrocarbons extractions that rises naturally to the surface. During the second phase, water and gas are injected in the well to push oil to the surface [3]. After the first two phases, there can be still $60-80 \%$ of oil left in the well [4]. The implementation of enhanced oil recovery (EOR) during the tertiary phase, can help extract up to $30 \%$ of original oil in place (OOIP). EOR involves injecting materials that aren't normally present within the reservoir to increase production. Enhanced oil recovery processes use thermal, chemical or fluid phase behavior effects to scale back or eliminate the capillary forces that trap oil within pores; to thin the oil or otherwise improve its mobility 
or to change the mobility of the displacing fluids. Reservoirs are composite environments that contains micro-organisms and minerals in which they interact with one another during a complex dynamic network of nutrients and energy flows. Since the reservoir is diversified, so the variability of ecosystems containing diverse microorganisms, which successively are ready to affect reservoir behaviour and oil mobility [5-8]. The aim of MEOR is to reinforce oil recovery consistently by making use of the metabolism indigenous or exogenous beneficial microbes. Several Studies on MEOR have been made, especially to tackle oil recovery challenges related to marginal fields. Example of such studies include the work of Koegler et al [9] who applied a dynamic screening tool for a high-salinity wintershall oilfield (186 g/l), anaerobic sand packs were established to simulate MEOR under defined laboratory conditions. Glass beads and quartz sand were used to produce porous media which varied in permeability, wettability, homogeneity and geochemistry. His result indicated that porous medium properties like permeability, pore size, wettability and mineralogy play a crucial role in MEOR efficiency. Maudgalya et al [10] reviewed 407 MEOR field trials worldwide. The field trials were classified according to these parameters; reservoirs' lithology and properties, microorganisms, nutrients, sort of test and sort of recovery mechanism. 333 field trials were applied following the well stimulation method out of the entire 407 field trials, 26 of the trials were made using water flooding and 44 were conducted as single well (huff puff scheme) applications. While details for the remaining 4 fields were not provided. His survey indicated that the primary mechanisms for MEOR were permeability profile modification, increase of capillary number (alcohols, biopolymers, acids and biosurfactants), biodegradation of heavy crude oil components making the oil less viscous and therefore the swelling of the oil due to the absorption of biogas ( $\mathrm{CO} 2$ and $\mathrm{CH} 4)$ within the oil phase. Review of the characteristics and results gotten from these 407 MEOR field tests stipulated that the desired results were gotten from the field trials.

\section{FUNDAMENTALS OF MEOR}

\subsection{History of MEOR}

Microbial enhanced oil recovery (MEOR) is a biological based technology consisting in manipulating function or structure, or both, of microbial environments existing in oil reservoirs with the ultimate aim of increasing oil production. J.W. Beckman [11] in 1926 proposed the utilization of microorganisms as one of the solutions to oil recovery issues. The use of microorganisms for oil recovery enhancement was later on patented by C.E ZoBell in 1946 [12], since then, numerous investigations hav been developed, and are extensively reviewed. In 1954, the primary field trial was administered within the Lisbon field in Arkansas, USA. During that point, Kuznetsov discovered the microbial gas production from oil. From 1954 to 1970s, in-depth research were made in USA, USSR, Czechoslovakia, Hungary and Poland. The main kind of field experiments made in those countries incorporated in injecting exogenous microorganisms. In 1958, selective plugging with biomass produced by microorganisms was proposed by Heinningen and colleagues. From 1970 to 2000, basic MEOR research concentrated on microbial ecology and the characterization of reservoirs. 1983, Ivanov and colleagues came out with the strata microbial activation technology. MEOR attained a multidisciplinary technology status in 1990. In 1995, a survey of MEOR projects (322) in the USA showed that $81 \%$ of the projects satisfyingly increased boring, and there wasn't one case of reduced boring [13]. Today, MEOR is gaining attention due to its low cost (less than \$10 per incremental bbl.) and low CAPEX requirement (the operator doesn't need to invest in surface facilities as traditional chemical or $\mathrm{CO}$ and may reduce the number of infill drilling wells) [14]. Figure 1 shows a breakdown of the worldwid recoverable petroleum reserves by types prepared by Meyer and Attanasi [15] and Schmitt [16].

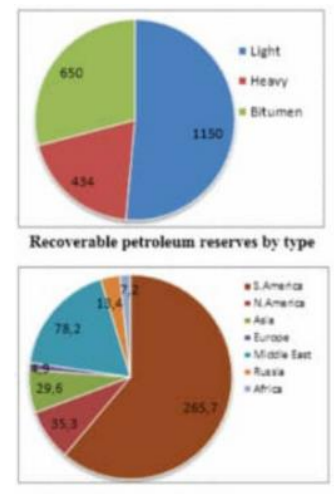

Heavy oil reserves by region

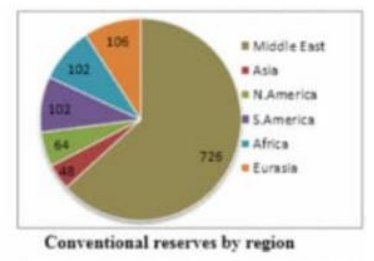

Conventional reserves by region

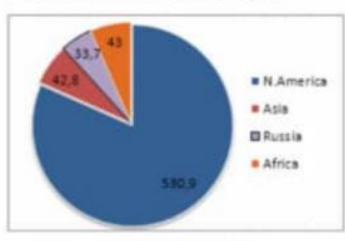

Bitumen reserves by region
Fig. 1. The current recoverable petroleum reserves in billions of barrels. (Source; Meyer and Attanasi [15] and Schmitt [16])

Figure 2 shows the cost estimation of different enhanced oil recovery techniques in USD per barrel.

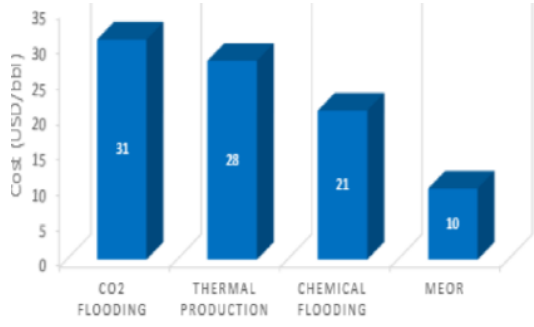

Fig. 2. Cost estimation of different EOR technique source [17] 


\subsection{MEOR Agents}

\section{Polymers, Surfactants and Acid}

Polymers, surfactants and acid stimulation required concentration is about $\mathrm{C}$ surfactant, acid $\sim 10^{-2}$ $\mathrm{kg} / \mathrm{kg}$ water and $\mathrm{C}$ polimer $\sim 10^{-3} \mathrm{~kg} / \mathrm{kg}$ water for attaining improved oil recovery [18]. The surfactant concentration needs to be this high to cover the absorption in the porous media. A. Hiorth et al [19] highlighted in their work that the quantity of polymer or surfactant that can be produced by the microbes present in the reservoir depends on the concentration of the microbes present in the reservoir. They further stated that microbial concentration in laboratory experiments ranges from $10^{5}-10^{9}$ microbes $/ \mathrm{ml}$. In the same reservoir where the growth conditions aren't optimal and a limited amount of nutrients is available the concentration will probably be close to $10^{6}$ cells $/ \mathrm{ml}$. The microbes have similar density to water and also has a radius as $r_{b}=1 \mathrm{\varphi m}$, that implies that the mass of spherical microbe is $m b=4 / 3 \pi \mathrm{r}^{3} \mathrm{bpw}=4 \cdot 10^{12} \mathrm{~g}$. They assumed that if the microbes can produce an amount of a chemical agent equivalent to their mass, then the concentration of the chemical is:

$$
\begin{aligned}
& \mathrm{C}=\left(10^{5}-10^{9}\right) \mathrm{Mb} / \mathrm{ml}, \\
& \mathrm{C} \approx\left(10^{-6}-10^{-2}\right) \mathrm{kg} / \mathrm{kg} .
\end{aligned}
$$

The result from the calculation compares well with Yakimov et al. [20] where the maximal concentration of microbes was $5.10^{8}$ cells $/ \mathrm{ml}$ and the maximal concentration polymer and surfactant was $(0.2-1.5)$ $\mathrm{g} / \mathrm{l}$ and $(0.05-0.15) \mathrm{g} / \mathrm{l}$ respectively. Let's assume a concentration in the reservoir is about $10^{5}$ microbes $/ \mathrm{ml}$ would then give $10^{4} \mathrm{~kg} / \mathrm{kg}$ water. That will be at least two orders of magnitude smaller than the concentration needed for an EOR effect, therefore a higher concentration of polymer or surfactant can be made available in a real reservoir situation. Surfactants are produced by microbes presents in the reservoir which helps in the reduction of interfacial tension of the oil. Biopolymers produced by microbial activities helps in viscosity modification of oil while acids are also produced to increase permeability and emulsification.

\section{Gas and Solvents}

The type of gases needed for MEOR are methane $\left(\mathrm{CH}_{4}\right)$ hydrogen and carbon dioxide $\left(\mathrm{CO}_{2}\right)$ due to microbial activity helps to increase pressure and reduction of interfacial section and viscosity while solvents are needed for the increment of permeability and viscosity reduction of the oil in the reservoir.

\section{Microbes}

Microbial flooding could be divided into indigenous microbial flooding and exogenous microbial flooding [21]. Indigenous microbes refer to microbes that were already present in the oil reservoir which were formed by the residual oil as the source of carbon on the basis of the functioning matter existing in formations and introducing air and the inorganic salt which contains phosphorus and nitrogen sources when water is injected, while exogenous microbes are the microbes that aren't in the reservoirs but were injected into to the oil reservoirs to increase boring [22].

\section{POSSIBLE APPLICATION OF MEOR FOR ENI OILFIELD}

\subsection{Field Background}

Eni oilfield lies in a water depth of approximately 40 feet and is positioned about eight (8) miles offshore West Niger Delta region in the southern part of Nigeria [23]. The field is made up of interstratified sandstones and shale units representing shore face to shelf deposition environment [24]. Eni oilfield reservoirs are located in NW-SE trending Miocene depocenters in a wave-dominated Niger Delta depositional system. The reservoir units occur as a part of the Agbada formation and comprises of stacked shallow marine fluvial-deltaic sediments separated by major marine shale units [25]. The sands were deposited in middle to upper shoreface, wave influenced environments. The likely sources of the hydrocarbons in the reservoirs are the underlying Eocene-Oligocene Akata marine shales. The oil field's depth varies from $48 \mathrm{ft}$ to $60 \mathrm{ft}$ [25]. Eni offshore field has recently been experiencing decline in oil production.

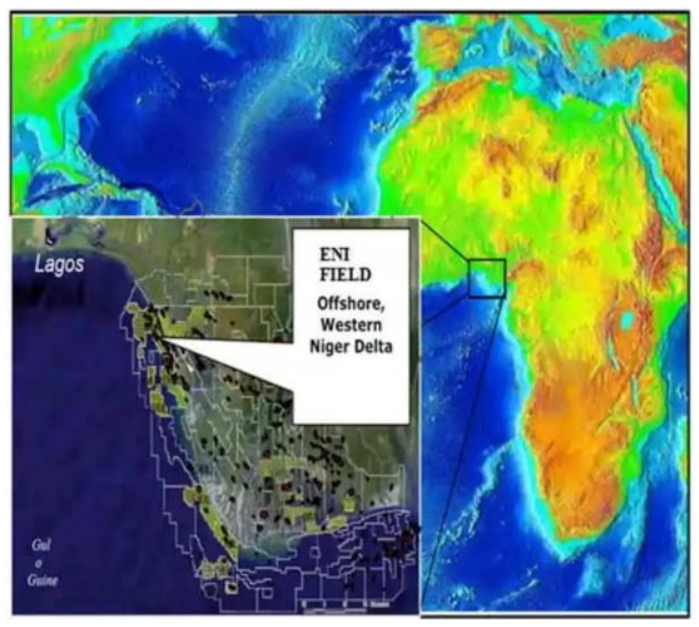

Fig. 3. Location od Eni field [23]

\section{Reservoir Parameters in Eni Field}

The summary of the reservoirs parameters in Eni offshore field is highlighted in Table 1. 
Tab. 1. Parameters for Eni Field reservoirs [26]

\begin{tabular}{cc}
\hline Data & Values in range \\
\hline $\begin{array}{c}\text { Average reservoir } \\
\text { temperature }\end{array}$ & $170^{\circ} \mathrm{F}-180^{\circ} \mathrm{F}$ \\
\hline Reservoir pressure & $2328-2553$ Psia \\
\hline Average porosity value & $0.238-0.241$ \\
\hline Water saturation & $0.127-0.13$ \\
\hline Average oil API & $20.5-34.2 \mathrm{API}$ \\
\hline Initial GOR & $350-390$ \\
\hline Oli viscosity & $0.57 \mathrm{cp}-2.57 \mathrm{cp}$ \\
\hline Gas viscosity & $0.65 \mathrm{cp}-0.67 \mathrm{cp}$ \\
\hline Boi & $1.33 \mathrm{Rb} / \mathrm{stb}-1.209 \mathrm{Rb} / \mathrm{stb}$ \\
\hline Relative permeability & $5048.27(\mathrm{md})$ \\
\hline Proved OOIP & $14 \mathrm{mmSTB}-43.08 \mathrm{mmSTB}$ \\
\hline
\end{tabular}

The cumulative production of one of the reservoirs (H10) in the field as of July 2016 is approximately $3.54 \mathrm{MMBO}$ which represents a $28 \%$ recovery factor. Well 3 is presently the only active completion well in the reservoir producing $157 \mathrm{bpd}, 2573 \mathrm{GOR}$ SCF/STB and $80 \%$ of water as of June 2016. Well 3 came on stream in march 2008 and produced 0.2 MMBO before quitting in January 2009 due to high water cut. The reservoir was initially saturated with pressure of 2553 Psi. the last measured pressure in well 3 in May 2014 was 2453 Psi indicating about $<5 \%$ pressure decline. Reservoir H10 is not under water injection, but gas lift optimization was introduced to improve the performance. However, the current performance is low [25], which brought about the reason for this study.

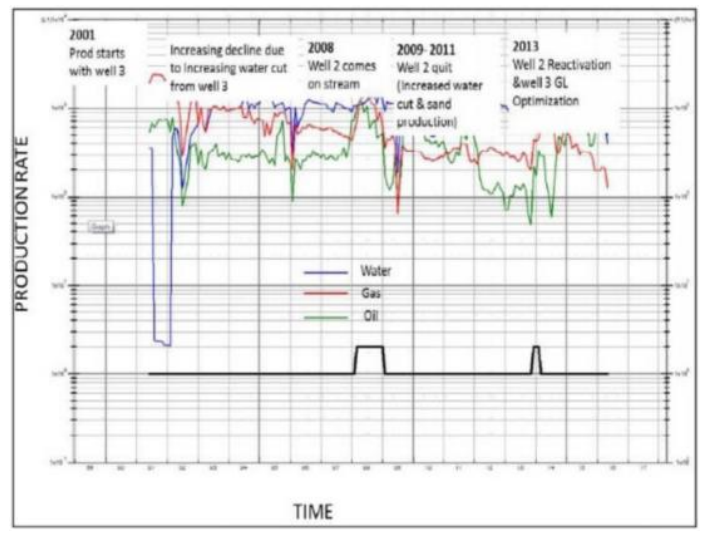

Fig. 4. Production performance plot od reservoir H10 in Eni oilfield [26]

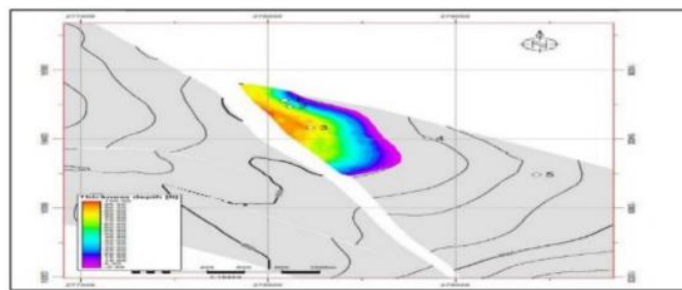

Fig. 5. Remaining net oil map of reservoir H10 in Eni Oilfield [26]

3.2. Stages for MEOR Application for Eni Oilfield

This paper suggests a three (3) stage approach for the application of MEOR for Eni oilfield for oil recovery.

1. Knowledge of the reservoir characteristics. Successful MEOR field application can only be obtained at the following reservoir conditions [10, 27]:

- reservoir temperature $<200^{\circ} \mathrm{F}$,

- brine salinity not more than $100,000 \mathrm{ppm}$,

- permeability above $30(\mathrm{mD})$,

- water depth not more than $3500 \mathrm{~m}$,

- pressure up to $20 \mathrm{mPa}$.

2. Reservoir stimulation to increase displacement efficiency. In this stage, stimulation of indigenous microbes can be achieved by injecting electron acceptors such as nitrates or easy fermentable molasses. In some cases, exogenous microbes can be injected to the oil reservoir. These microbes will produce MEOR agents such as biomass, biofilms, surfactants, biopolymers, solvents, acids and gases. Surfactants produced by Acinetobacter, Bacillus Sp, Arthrobacter and Pseudomonas helps in emulsification and deemulsification process through reduction of interfacial tension of the oil. Biopolymers produced by sclerotium Sp, Bacillus $\mathrm{Sp}$, Aureobasidium Sp and Brevibacterium helps in viscosity modification of the oil in the reservoir. Solvents such as acetone, butanol, propan-2-diol produced by clostridium helps in rock dissolution for increasing permeability and also oil viscosity reduction. Acids such as propionic and butyric acids produced by Clostridium and enterobacter microbes helps to increase permeability and emulsification while clostridium, Enterobacter and Methanobacterium produces gases which increases pressure, oil swelling, reduction of interfacial section and viscosity as well as increasing permeability in the reservoir [22].

3. Enhance water flooding for oil recovery through selective plugging. After stage 2 of MEOR Process, some percentage of oil are still trapped by rocks in the reservoir, more oil can be recovered at this stage. Low salinity water flood can be made to drive away trapped oils after conditioned cells and extracellular polymeric substances called exopolysaccharides secreted by 
microbes to protect themselves from drying out or falling prey to other organisms in the reservoir plug high permeability zones and pores in the reservoir so that oil may move past rock surfaces more easily, resulting in a change of the direction of water flood to oil-rich channels thereby increasing the sweep efficiency of oil recovery with water flooding. Since microbial produced surfactants had already reduced the interfacial tension, a lower hydrostatic pressure will be needed to move the fluid to overcome capillary effect. The gases produced by the microbes will help in reducing the viscosity of the oil thereby improving the flow rate of the oil thereby making it possible for oil recovery

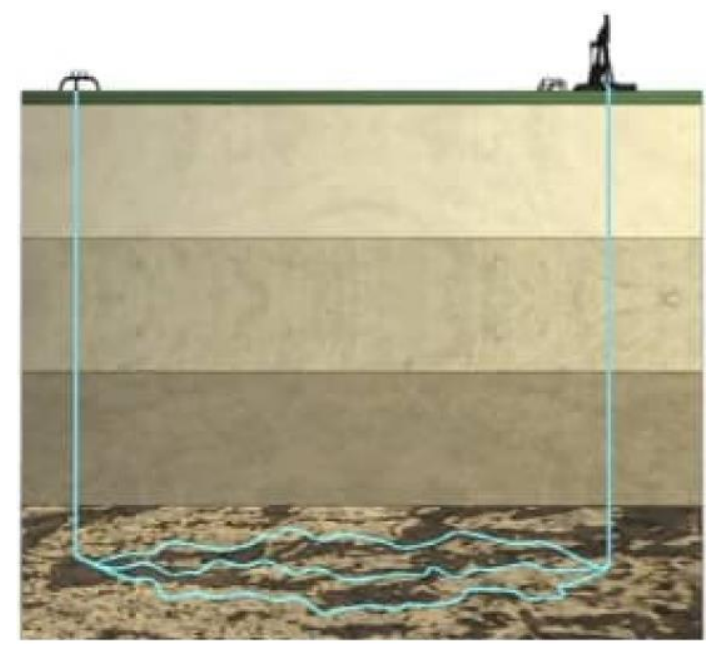

Fig. 6. Water flooding process in an oil reservoir [14]

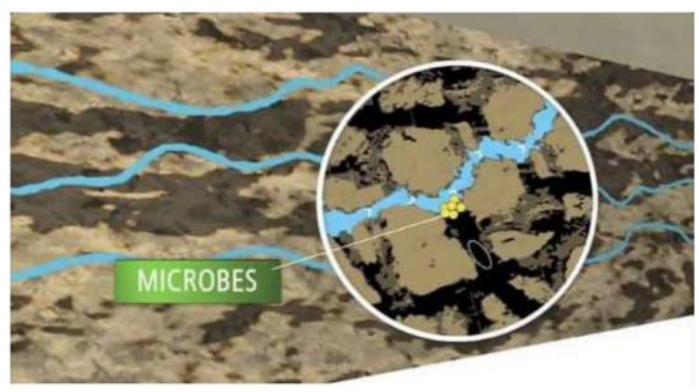

Fig. 7. Indigenous microbes found in an oil reservoir [14]

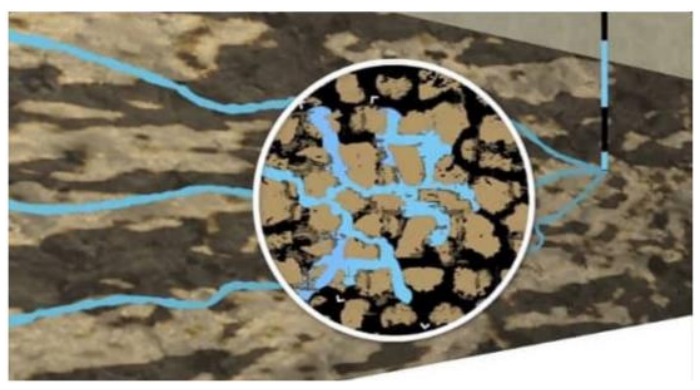

Fig. 8. Selective plugging process in an oil reservoir [14]

\section{DISCUSSION}

In order to boost production in Eni's offshore oilfield, Microbial enhanced oil recovery method (MEOR) was suggested due to its high efficiency, environmental friendliness and economic viability. The reservoirs parameters of the field were found suitable for MEOR application as its maximum temperature was $180^{\circ} \mathrm{F}$, maximum pressure 2553 Psia, maximum porosity value 0.241 and a relative permeability of 5048.27 (md) met up with the conditions for a successful MEOR application. The required concentration of microbes for effective oil recovery was highlighted in this study. The reservoir stimulation can be achieved with parameters gotten from Eni's field as the microbes can survive conveniently and actively in this conditions. These microbes will produce MEOR agents such as biomass, biofilms, surfactants, biopolymers, solvents, acids and gases which will stimulate the fluid in the reservoir by increasing permeability and emulsification, reducing interfacial section and viscosity in the reservoir for easy oil recovery. MEOR advantages are outlined as follows:

- increase of the productivity of the oil field [28],

- MEOR set up is less expensive [17],

- low energy input requirement for microbes to produce MEOR agents [28],

- an increase of light alkanes < C2O in the quality of the oil produced [28],

- transformation of sulphur - containing organic compounds of the oil [28],

- splitting of phenolic ring chemical structures [28],

- splitting of aromatic ring structures [28].

\section{CONCLUSIONS}

Eni oilfield located in the western part of Niger Delta region of Nigeria has been experiencing production decline with increase in water output. Gas lift optimization was introduced to improve the performance but was not efficient for oil recovery in the field as the current performance is still low. This study suggested MEOR an alternate oil recovery technique which has the potential to curb such challenges.

MEOR technology makes use of indigenous or exogenous microbial strains and nutrients that are injected into the reservoir to enhance oil production. This study demonstrated that the most important criteria for selecting a reservoir for MEOR applications are the reservoir temperature, reservoir pressure, brine salinity, water depth and the relative permeability of the reservoir. The following metabolites interact with the crude oil changing its physiochemical properties; acids, biomass, solvents, biopolymers, biosurfactants and biogases. The implementation of MEOR on Eni field requires low 
capital investment; while it offers high efficiency and its environmental friendly.

\section{References}

1. "Oilfield" https://www.investopedia.com. Retrieved 2020-08-1.

2. "BP Statistical Review of World Energy (2015)" British Petroleum, June 2015.

3. G. Glatz (2013) "A primer on Enhanced Oil Recovery" physics 240, Stanford University, Fall 2013.

4. A.Z Abidin, T. Puspasari, and W.A. Nugroho, (2012) "Polymers for Enhnaced Oil Recovery Technology" Procedia Chem . pp. 4,11.

5. Ollivier, B. and M. Magot, eds. Petroleum Microbiology. Ist ed. 2005, ASM Press: Washington Dc. 365

6. Sen, R., (2008) "Biotechnology in Petroleum Recovery: The microbial EOR. Progress in Energy and Combustion Science. 34 (6): pp. $714-724$.

7. Van Hamme, J.D; A. Singh, and O.P Ward, (2006) "Petroleum Microbiology - Part 1: Underlying Biochemistry and Physiology. Chimica Oggi Chemistry Today .24 (1) pp. 52.

8. Awan, A.R.R. Teigland and J. Kleppe (2008) "A survey of North Sea Enhanced Oil -Recovery Project Initiated During the Years 1975 to 2005. Spe Reservoir Evaluation and Engineering. 11(3) pp. 497 - 512.

9. F. koegler, E. Mahler, N. Dopffel, D Schulze Makuch, A. Borovina, F. Visser, A. Herold, H. ALkon (2020) "The MEOR Potential of Halanaerobiales under dynamic conditions in different porous media. Journal of Petroleum Science and Engineering.

10. Maudgalya S, Knapp RM, Mclnernery MJ. (2007) "Microbial Enhanced Oil Recovery Technologies: A review of the past, present and future. IN: SPE Production and Operations Symposium; March 31 April 3 2007. pp. 1-11 SPED 106978.

11. Beckman Jw (1926) "The Action of Bacteria on Mineral Oil" Industrial and Engineering Chemistry; New Edition 1926; 4:23-26.

12. Zobell CE. (1947) "Bacterial Release of Oil from OilBearing Materials. World oil 1947; 26:36 - 47.

13. Lazar, I, I.G. Petrisor, and T.E. Yen, (2007) "Microbial Enhanced Oil Recovery (MEOR). Petroleum Science and Technology. 25 (11-12): pp. 1353-1366.

14. "New Aero Technology/Sweep the Unswept". New Aero Technology. Retrieved 2020 -08-15.

15. Meyer RF, Attanasi E. Heavy Oil and Bitumum Strategic Petroleum Resources. U.S. Geological Survey Fact Sheet 2003 -7-03. http://pubs.usgs.gov/fs/fs07003/fs5070-03.html.

16. Schmitt DR. (2005). "Heavy and Bituminous Oils: Can Alberta Save the World/Australian SEG Preview Magazine. 2005; 118:22-29.

17. Q.cui, (2017) "Recent Progress in MEOR Technology in Low-Medium Permeability Reservoirs in Proceedings of 7 th Chemical flooding Enhanced Oil Recovery Conference, Chinese Petroleum Society, PP.; 1-9, Dalian, Lianoning Province, China, 2017.

18. Green D. and Wilhite G; (1998) "Enhanced Oil Recovery" Society of Petroleum Engineers; USA.

19. Aksel Hiorth; Krista Kaster, Arild Lohne, Ola k. Siqveland, Harald Berland, Nils H. Giske and Arne Stavland (2007) "Microbial Enhanced Oil Recovery Mechanism" Presentation at International Symposium of the Society of Core Analysts, Calgary, Canada 10-13 September, 2007

20. S. Zahid and H.A Khan, (2007), "A Review on Microbial EOR with Special Reference to its use in
Marginal and/or Mature Assets", In Proceedings of International Oil Conference and Exhibition in Mexico, PP. 1-9, Veracruz, Mexico.

21. J. He, Y. Wang and G. Liang (2018), "Emerging Strategical Technology of the Oilfield Development, Petroleum Industry Press.

22. Shurler, M.L. and F. Kargi (2001), "Bioprocess Engineering: Basic Concepts". International Series in the Physical and Chemical Engineering Science. Prentice - Hall 576

23. Osinowo OO, Ayorinde JO, Nwankwo CP, Ekeng OM, Taiwo OB (2017) "Reservoir Description and Characterization of Eni field Offshore Niger Delta, Southern Nigeria. Journal of Petroleum Exploration and Production Technology.

24. Cook G, Chawathe A, Larue D, Legarre H, Ajayi E (1999) "Incorporating Sequence Stratigraphy in Reservoir. An integrated Study of the Meren E01/MR05 Sands in the Niger Delta. Houston (Texas). In:Paper SPE 51892 presented at the SPE Reservoir Simulation Symposium, pp. 14-17

25. Poston Sio. Berry P. Molokwu Fw. (1981) "Meren Field: The geology and Reservoir Characteristics of a Nigerian Offshore Field, Paper SPE 10344 Presented at the SPE Annual Technical Conference and Exhibition, San Antonio 1981.

26. Janet Ayorinde, O.O Osinowo, P. Nwankwo. (2019) "Integrated Approach to Reverse to Reverse Estimation and Reservoir Simulation of Eni Offshore Field, In Niger Delta, Nigeria. Current Journal of Applied Science and technology, 38 (6), pp. 1-14.

27. Fujiwara, K, Y Sugai, N. Yazawa, K. Ohno. C. X. Hong and H. Enomoto. (2004). "Biotechnological Approach for Development of Microbial Enhanced Oil Recovering Technique. Petroleum Biotechnology; Developments and Perspectives, 2004. 151, pp. 405445 .

28. Guseva U.Z Ovsyannikova Vs, Svarovskaya Li, Altunina Lk, "Role of Microorganisms During EOR". http://www.pc.tsc.ru/proekts/1/10/index.htm (in Russian). 


\section{Biographical notes}

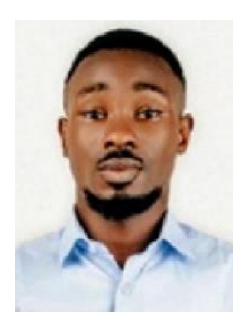

Nsisong E. Udosoh holds a bachelor's degree in Marine Engineering from Akwa Ibom State University,Nigeria. $\mathrm{He}$ is currently undergoing a master's degree in Marine Engineering with specialty in Offshore Engineering at Federal University of Petroleum Resources, Delta State, Nigeria. His research interests are in oil and gas pipeline design and modelling, design of offshore structures, subsea production systems, reservoir stimulation and enhance oil recovery (EOR), mechanic of ocean waves and the applications of artificial intelligence in offshore engineering industry.

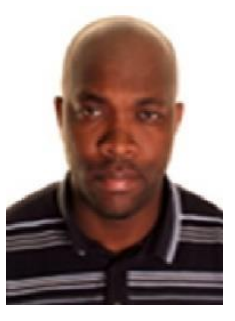

Thaddeus Chidiebere Nwaoha obtained his $\mathrm{PhD}$ in Marine and Offshore Technology and MSc in Marine and Offshore Engineering from Liverpool John Moores University, UK in 2011 and 2006 respectively. His professional experiences comprise of academic and industrial experiences in LNG carrier system maintenance and risk modeling, inspection of topside and subsea equipment, quality assurance, safety, risk and reliability analysis of marine and offshore systems. He has served as an inspection, quality assurance, safety and reliability engineer in marine and offshore companies and a member of professional bodies such as IMarEST, NSE, NIMENA and COREN. Since 2010, he has authored and co-authored more than 46 journal papers in world leading journals. His research interests are system failure analysis, design for safety of marine and offshore system, optimization, maintenance modeling and risk/reliability analysis. Currently, he serves as a senior lecturer in Marine Engineering Department, Federal University of Petroleum Resources, Nigeria and marine/offshore risk engineering consultant for various companies. 
